\title{
Problems of increased transport load as a result of implementation of projects of high-rise constructions
}

\author{
Ivan Provotorov ${ }^{1, *}$ Valentin Gasilov ${ }^{1}$, and Nadezhda Anisimova ${ }^{1}$ \\ ${ }^{1}$ Voronezh State Technical University, Moscow Avenue, 14, Voronezh, 394026, Russia
}

\begin{abstract}
The structure of problems of high-rise construction us suggested, which includes the impact on environment, design solutions, transportation problems, financial costs for construction and operation, and others. Positive and negative aspects of high-rise construction are considered. One of the basic problems of high-rise construction is the problem of increased transport load. Construction of the subway on the basis of the concession mechanism, with the use of unmanned control of rolling stock is proposed as the most expedient solution. An evaluation of the effectiveness of this project is presented, it shows quite high performance indicators for a private investor. Main problems that the project implementation may face in conditions of lack of scientific and methodological support are outlined.
\end{abstract}

\section{Introduction}

Scientists note that the increase in the number of urban population and the need to ensure comfortable living conditions in the face of a shortage of land resources (especially in central parts of cities) leads to the need for building high-rise buildings around the world [1]. In scientific and industrial community there are two different opinions about the expediency of construction of high-rise buildings in Russia. According to the first one, positive aspects of such construction are noted. High-rise buildings contribute to the development of the economy, business and tourism. [2]. Second one Second one states that there are significant land resources in Russia and there is no need for the erecting high-rise buildings [3]. Authors of this study Without taking unequivocally both positions, the authors of this study hold the view that the construction of high-rise buildings is an extremely complex area, which, of course, has both positive and negative sides. A similar approach is used in a number of scientific papers [4]. At the same time, the tendencies occurring in foreign countries show an increase in the volume of such construction, which indicates that the construction of high-rise buildings is a trend of the current stage of development. Russian reality demonstrates a significant interest in the problems of high-rise construction, which is indicated, in particular, by the regular holding of the international high-rise and unique construction forum 100+ Forum Russia, for example in 2017 it was visited by 6,112 participants, including representatives of 97 Russian cities, 22 official delegations from cities and regions of Russia $[5]$.

\footnotetext{
* Corresponding author: ivanprovotorov@yandex.ru
} 


\section{Materials and Methods}

Problems arising during the development and implementation of high-rise construction projects require systematization and the search for optimal methods for overcoming them. Problem of high-rise construction is quite common in scientific literature, basically it concerns design, technical, technological, financial and economic aspects. But specific directions are also considered, for example, psychological aspects that need to be considered in the design of high-rise buildings $[6,7]$. Along with it, they do not emphasize the search for comprehensive ways to solve the problem.

The analysis of scientific papers, sectoral studies and practice of implementing high-rise construction projects allows us to highlight the problematic field of such projects. Table. 1 presents systematized problems of the implementation of high-rise construction projects.

Table 1. Problems of high-rise construction projects implementation

\begin{tabular}{|c|c|c|}
\hline Positive aspects & Problem & Negative aspects \\
\hline $\begin{array}{l}\text { In projects of high-rise construction, modern } \\
\text { ecological materials and structures are often } \\
\text { used. There is an opportunity to use } \\
\text { technologies based on renewable energy } \\
\text { sources. }\end{array}$ & $\begin{array}{c}\text { Impact on } \\
\text { the } \\
\text { environment }\end{array}$ & $\begin{array}{l}\text { Increase the burden on the environment, taking } \\
\text { into account the increase in population density. }\end{array}$ \\
\hline $\begin{array}{l}\text { Development of building science and practice. } \\
\text { The use of advanced materials and structures. }\end{array}$ & $\begin{array}{l}\text { Project } \\
\text { solutions }\end{array}$ & $\begin{array}{l}\text { Design solutions become more complicated due } \\
\text { to the complexity of the construction task and } \\
\text { emerging risks. }\end{array}$ \\
\hline $\begin{array}{l}\text { The construction of complex high-rise } \\
\text { buildings that combine leisure, business, } \\
\text { residential, commercial areas reduces the } \\
\text { impact on the transport network. }\end{array}$ & $\begin{array}{l}\text { Transport } \\
\text { problem }\end{array}$ & $\begin{array}{l}\text { Increased load on the road network, passenger } \\
\text { vehicles. Increase in traffic congestion, increase } \\
\text { in travel time. Additional costs for transport } \\
\text { infrastructure improving. }\end{array}$ \\
\hline $\begin{array}{l}\text { Minimization of the land component in the cost } \\
\text { of construction. Reducing the cost of obtaining } \\
\text { permits (in comparison with the construction } \\
\text { of several objects). Reducing the cost of } \\
\text { relocation of workers, machines and } \\
\text { mechanisms. In the central parts of the cities, } \\
\text { in most cases, there are few land resources left. }\end{array}$ & $\begin{array}{c}\text { Financial } \\
\text { costs of } \\
\text { construction } \\
\text { and } \\
\text { operation }\end{array}$ & $\begin{array}{l}\text { The increase in construction costs due to the } \\
\text { complexity of the construction process, the } \\
\text { uniqueness of buildings, the need to use modern } \\
\text { expensive materials and design solutions. A } \\
\text { significant part of the internal volume of the } \\
\text { high-rise building is not used. The requirements } \\
\text { for structures and their cost are increasing. High } \\
\text { cost of repair and maintenance }\end{array}$ \\
\hline $\begin{array}{l}\text { High-rise construction allows the use of } \\
\text { energy-efficient technologies aimed at saving } \\
\text { resources. }\end{array}$ & $\begin{array}{c}\text { Impact on } \\
\text { engineering } \\
\text { infrastructur } \\
\mathrm{e}\end{array}$ & $\begin{array}{l}\text { Increased load of the engineering infrastructure, } \\
\text { calculated for a certain number of users. } \\
\text { Accelerated wear of equipment under the } \\
\text { influence of increased load. Exploitation requires } \\
\text { more resources }\end{array}$ \\
\hline $\begin{array}{l}\text { Living in high-rise buildings is associated with } \\
\text { success, prestige. The presence in the building } \\
\text { of commercial and business facilities increases } \\
\text { the comfort of living. }\end{array}$ & $\begin{array}{l}\text { Psychologic } \\
\text { al aspects, } \\
\text { comfort of } \\
\quad \text { living }\end{array}$ & $\begin{array}{l}\text { Living in high-rise buildings can lead to the } \\
\text { emergence and development of various phobias, } \\
\text { including fear of height or confined space. There } \\
\text { may be a different kind of psychological } \\
\text { discomfort. }\end{array}$ \\
\hline $\begin{array}{l}\text { Modern solutions aimed at creating a } \\
\text { comfortable environment in high-rise buildings } \\
\text { can positively influence the health of residents } \\
\text { (for example, air purification). Reduced noise } \\
\text { for residents of the upper floors. Cleaner air on } \\
\text { the upper floors. }\end{array}$ & $\begin{array}{l}\text { Impact on } \\
\text { the health of } \\
\text { the resident } \\
\text { of } \\
\text { population }\end{array}$ & $\begin{array}{l}\text { There are studies showing the occurrence of } \\
\text { negative health effects from living in high-rise } \\
\text { buildings. Deterioration of bacteriological } \\
\text { protection of the population. Strong wind on the } \\
\text { upper floors. }\end{array}$ \\
\hline $\begin{array}{l}\text { The impact can be less than the combined } \\
\text { effect of erecting several objects of a smaller } \\
\text { number of storeys. }\end{array}$ & $\begin{array}{l}\text { Impact in the } \\
\text { process of } \\
\text { construction }\end{array}$ & $\begin{array}{l}\text { negative impact of high-rise construction projects } \\
\text { on adjacent territories during the construction } \\
\text { period is possible. It will consist in the } \\
\text { deterioration of the living environment for the } \\
\text { population living near the construction site }\end{array}$ \\
\hline $\begin{array}{l}\text { Modern video monitoring and security systems } \\
\text { allow you to minimize the risks of living. }\end{array}$ & $\begin{array}{l}\text { Security of } \\
\text { residence }\end{array}$ & $\begin{array}{l}\text { Increased fire risk, increased risks of terrorist } \\
\text { attacks and illegal actions. Complexity of } \\
\text { evacuation in case of emergency. }\end{array}$ \\
\hline
\end{tabular}


Aspects of problems of high-rise buildings construction above are not exhaustive, but they allow us to estimate positives and negatives of erecting such object, and to develop measures aiming at minimizing negative impacts. In this paper, we consider the transport aspect, as one of the most important.

We will consider problems of high-rise construction and ways of solving transport problems on Voronezh-city example (Russia). It is situated in European part of Russia, in 515 $\mathrm{km}$ to the south-south-east of Moscow. Population is above one million people. There are few high-rise buildings in the city. In the coming years, it is planned to put into exploitation several high-rise residential buildings, including a 100-meter high residential building. Along with it, last years are characterized by residential buildings construction, maximum height of which is near to $75 \mathrm{~m}(74,16 \mathrm{~m}$ and $74,56 \mathrm{~m})$. This is largely due to the reluctance of developers to exceed the height of $75 \mathrm{~m}$, which, in accordance with domestic regulations, is the criterion for classifying a building as a high-rise. The reasons are increased The reasons are an increase in the requirements for this kind of facilities, as well as the unavailability of fire departments to eliminate the consequences of fires in high altitude facilities. Fire safety of high-rise buildings is one of the most important problems, it is noted that for the development of high-rise construction, financial support should be provided to improve firefighting and rescue equipment.

Along with it, the main problem, which At the same time, the main problem hampering the development of high-rise construction in Voronezh should be recognized the problem of the transport sector, which has been operating in the regime of significant overload over the past decade. At the beginning of 2017 the city of Voronezh took the third place in Russia in terms of motorization of the population, which amounted to 308 vehicles per thousand people. This indicator shows both positive aspects - growth of living standards and mobility of the population, as well as negative ones - increasing the negative impact from motor transport, and increased load on transport infrastructure.

Since the beginning of 21-st century motorization level in Russia increased highly, and motor transport market became one of the most dynamically developed in Europe. Despite the fact that the period from 2014 to 2017 became pretty heavy (for example, in 2014, the level of cars sale fell by about $10 \%$ ), we should expect the increase in motorization level of population. This can be concluded on the basis of comparison with foreign countries figure 1 .

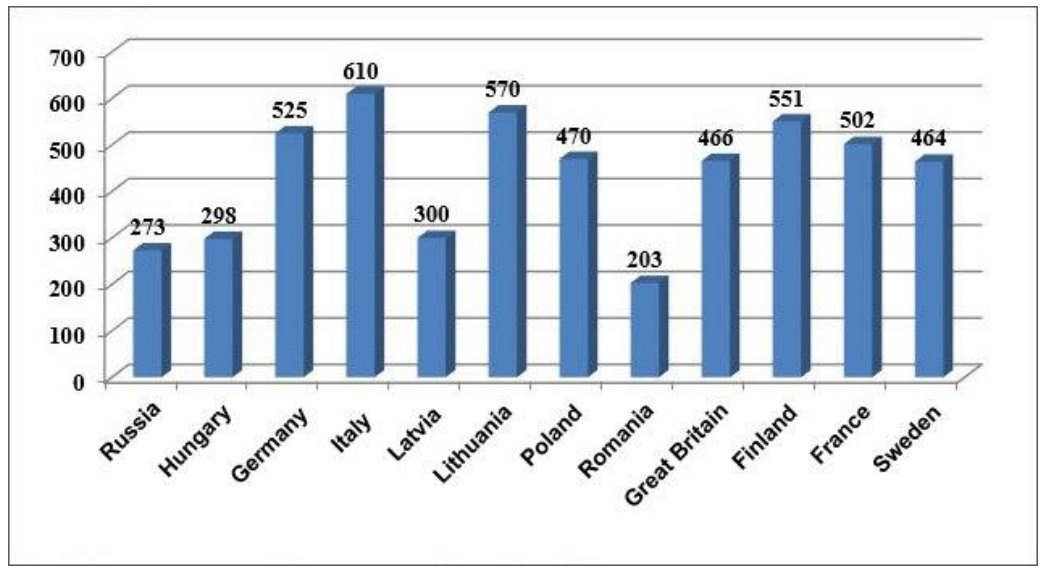

Fig.1. Motorization level in Russian Federation and different world states, passenger cars on one thousand people of population [8]

At the same time, it should be noticed that a significant lag of motorization level from developed foreign countries allows us to say, that in near years after the end of economic 
crisis, the significant increase in fleet of vehicles will take place (due to deferred demand). This will lead to increase in the intensity of traffic and will cause an even greater burden on the road network.

The volume of cars of all types production in Russia is decreasing under low demand level influence. The decrease in the incomes of the population also reduces the traffic volumes. As a result, transport problem is not taken serious in last years. This creates prerequisites for "explosive" increase in traffic intensity in the period of overcoming the crisis phenomena because of vehicle acquisition due to delayed demand. Thus it is necessary to develop the set of measures to overcome these inevitable phenomena that could have a significant impact on transport complex [9].

One of the most actual areas for transport problem solving in Voronezh is a subway construction project. Unfortunately, lack of funds does not provide an opportunity to implement such project. A new round of development of the subway construction project in Voronezh began in April 2017, during the visit of the Japanese delegation to Russia. During meeting, various issues related to the development of the urban environment and the participation of Japanese architects and developers were discussed, including the construction of the metro. After 2 months, an open tender was announced for work on the feasibility study for the creation of an urban high-speed rail passenger transport system.

As a result of the feasibility study, the following work was carried out by the following schedule:

- I stage until 31 July of 2017;

- II stage until 31 August of 2017;

- III stage until 20 December of 2017.

During the substantiation of the economic part of this project, the authors of this study evaluated the effectiveness of the investment project. Calculations show that the total amount of investment for the construction of the first stage of the metro, taking into account the rise in cost of construction and rolling stock, will be about 48.344 billion rubles (about 0.7 billion euros). As a result of the calculations, the problem of insufficient indicators of the project's effectiveness is revealed, which does not allow to return the invested funds at the desired time. The feasibility of integrated automation of metro lines is being studied, allowing unmanned rolling stock management, which can be one of measures aimed at improving the efficiency of the project. This is consulted with general designer. This measure allows you to reduce labor costs, which should lead to increased profitability. At the same time, complex automation causes additional costs for rolling stock and the creation of integrated automated control systems.

In view of the complexity of implementing the project only at the expense of budget funds, the basic option is the scheme of infrastructure concession. According to the Federal Law "On concession agreements," objects of the concession agreement may be subways and other public transport $[10,11]$.

\section{Results}

Based on the comparison of various options for the implementation of the subway project on a concession basis, a financing option for the project was chosen when the state finances the project at the initial stage (the first 4 years), and for 5-th year the private investor will make all investments in the amount of 19762.655 million rubles (about 286 million euro), which will amount to $40.879 \%$ of the total investment under the project. To determine the feasibility of the project, the project's cash flows for the concessionaire were modeled - figure 2. 


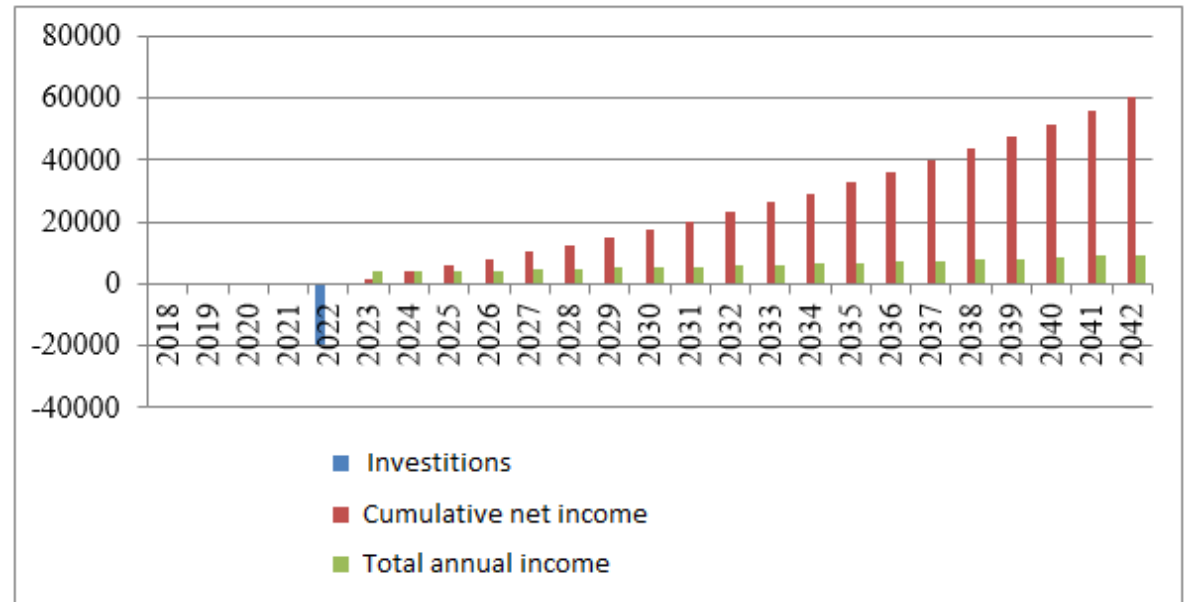

Fig. 2. Modeling of cash flows of a subway construction project for a concessionaire

The calculations show sufficient performance indicators for the concessionaire:

- $\quad \operatorname{IRR}=12 \%$;

- $\quad \mathrm{DPP}=15,76$ year;

- $\mathrm{NPV}=3094,852$ million rubles (about 45 million euros);

- $\quad \mathrm{DPI}=1,172$.

\section{Discussions}

The problem of ensuring the efficiency of the transport network for the development of high-rise construction requires more attention from the scientific community, since it is one of the basic problems. The proposed project of creating high-speed rail passenger transport will involve certain risks. This is connected to the complex technical task of constructing the most complex facility, financial and economic risks, and social risks associated with the implementation of the project on the existing transport and residential system of the city. An assessment of the readiness of the theoretical and methodological framework for implementing such projects on the basis of work $[12,13]$ shows a rather low preparedness of Russian reality for the implementation of such projects. One of the main problems in the implementation of the subway construction project is the difficulty of providing the required passenger traffic ( 300 thousand people a day on average in 2023). In addition, a significant amount of investment in the project in the conditions of economic instability in the country's economy is required. Currently, it is necessary to develop approaches to improving the effectiveness of such projects [14].

\section{Conclusion}

Solving the basic problems associated with the construction of high-rise buildings is the main condition for the development of this direction. The approaches to solving the problem presented in this paper can be relevant for a number of cities, faced with the difficulties of providing favorable transport conditions for the development of high-rise construction.

\section{References}


1. V.P. Generalov, E.M. Generalova, Bulletin of SASU, 1 (18), 13-18 (2015)

2. L.V. Tolstoy, R.G. Abakunov, Innovative Science, 1-1, 100-103 (2017)

3. E. Kalcheva, A. Takia, Y. Hadi, Social and Behavioral

4. I.V. Ilin, A.B. Anisiforov, WSEAS Transactions on Business and Economics, 11, 757764 (2014)

5. V.V. Gluhov, I.V. Ilin, Lecture Notes in Computer Science, 8638, 509- 518, (2014) DOi10.1007/978-3-319-10353-2_46

6. K. Olga, Intern. Journal of Economics and Financial Issues, 6, 995- 1002 (2016)

7. O.V. Kalinina, M.V. Lopatin, Actual Problems of Economics, 182, 392-405 (2016)\DOI: 10.1016/j.sbspro.2015.12.093.

8. Yu.S. Dvirnik, Scientific almanac, 4-3(30), 52-54 (2017) DOI: 10.17117/na.2017.04.03.052.

9. J. Tamošaitienėa, E. Gaudutisb, M. Kračkaa, Procedia Engineering, 57, 1151-1155 (2013) DOI: 10.1016/j.proeng.2013.04.145

10. C. Haitaoa, L.Leileic, Q.Jiuzid, Procedia Engineering, 43, 23-27 (2012) DOI: 10.1016/j.proeng.2012.08.005

11. P. Fenga, W. Xingkuan, Procedia Engineering, 21, 943-947 (2011) DOI: 10.1016/j.proeng.2011.11.2098

12. V.A. Kazarnovskiy, L.A. Manuhina, L.V. Katina, Economics, Management, 1, 44-47 (2015)

13. K.A. Karelina, APRIORI, 1, 1-11 (2016)

14. V. Gasilov, N. Anisimova, I. Provotorov, MATEC Web of Conferences, 106, 08035 (2017) DOI: 10.1051/ mateconf / 201710608035 